\title{
Identification of economically important diseases and insect pests of prioritized aromatic and medicinal plants in Ethiopia
}

\author{
Mihiret Mekonnen ${ }^{1 *}$ and Begashaw Manahlie ${ }^{2}$ \\ ${ }^{1}$ Wondo Genet Agricultural Research Center, EIAR, P.O.Box. 198, Shashemene, Ethiopia \\ ${ }^{2}$ Hawassa University, College of Natural and Computational Sciences, P.O. Box 5, Hawassa, Ethiopia
}

*Corresponding author: hanamihiret0@gmail.com

\begin{abstract}
Aromatic and medicinal plants occupy an important place in the socio-cultural, spiritual and health care aspects in Ethiopia. Their use for cosmetic, medicinal, coloring and aromatic purposes has a long tradition. However, diseases and insect pests are major limiting factors for the cultivation and production of these plants in many agro-ecologies of the country. Therefore, the aim of this study was to identify diseases and insect pests of prioritized Aromatic and medicinal plants in different agro-ecologies of Ethiopia. The study was conducted at six locations from 2012 to 2015. Infected parts of prioritized AMPs were randomly collected from Wondo genet, Holata, Debrezeith, Qoqa, Alage and Hawassa for laboratory evaluations. Tissue segments of each plant were agitated in $10 \%$ sodium hypochlorite for 2 minutes and then rinsed three to four times in sterile distilled water. Five pieces of each plant tissues were cultured on PDA media with five replications and then incubated at room temperature for 7 to 10 days. Vegetative hyphae and shape of conidia of pure cultures of each fungal colony were identified under microscope. The identified fungi were described and grouped into different fungal genera. Similarly, samples were randomly collected from insect infested plants from each study location for laboratory inspection. Specimens of unidentified insects were kept in vials containing ethanol for identification. All specimens were classified into their respective orders, families, genera and species. Generally, the result raveled that Fusarium spp., Phoma spp., Rust and Powdery mildew were the major identified fungal diseases and aphid is a common insect pest recorded.
\end{abstract}

Keywords: Aphid, Fusarium spp., Phoma spp., Powdery mildew, Rust. Abbreviations: MAPS_medicinal and aromatic plants, PDA_Potato dextrose Agar.

\section{Introduction}

Medicinal and aromatic plants (MAPs) are receiving considerable attention all over the world because of their vast untapped economic potential, especially in the use of herbal medicines. They offer a wide range of safe and cost-effective, preventive and curative therapies, which enhance the health and security of local people (Rashi and Singh, 2007). As per the estimates of the World Health Organization, over 80 per cent of the world's population relies on traditional medicines, largely plant-based, for primary health care (WHO, 2002).

Ethiopia possesses a wide range of potentially useful medicinal plants, more extensive indeed than available in many other parts of the world (Yirga, 2010b). Abebe (1986) estimated that $95 \%$ of traditional medical preparations in Ethiopia are of plant origin. Thus these plants play indispensable roles in daily life and are deeply connected to diverse social, cultural, and economic events. The attraction of medicinal and aromatic plants as worthy farm crops has grown due to the demand created by consumer interest in these plants for culinary, medicinal, and other anthropogenic applications. With the increased cultivation of medicinal and aromatic plants, pest and disease problems are also increasing; some of the pests are mites of different groups (Gupta, 2005). In recent years, there have been rising expectations that aromatic and medicinal plants might become cash crops, with large added value and large revenues for local people (JAICAF, 2008). For such Table 1. Site descriptions for the six study locations. expectations to become a reality, Wondo Genet Agricultural Research Center is involved in collection and cultivation of MAPs from their natural ecosystems at different agroecologies of Ethiopia. To achieve its goals, the center is disseminating improved technologies to local communities in different agro-ecological zones.

However, besides traditional cropping uncertainties of weather, diseases are major limiting factors for the cultivation and production of AMPs in the country. Like other crop plants, AMPs are susceptible to many diseases like leaf spots, leaf blight, root rot and wilt and cause serious damages (Singh et al., 2011). Diseases are frequently occurred on these plants at different cultivation areas of Ethiopia (Mihiret et al., 2015a, Mihiret et al., 2015b). Despite this, relatively little attention has been paid to the study and identification of potential diseases associated with these plants in the country. Therefore, the aim of this study was to identify economically important diseases and insect pests of prioritized aromatic and medicinal plants at different agroecologies of the country.

\section{Results}

In this study, six fungal isolates namely, $P$. nakanishikii, $P$. menthae, A. solani, U. aloes Fusarium spp. and Phoma ssp., were examined using light microscope. The isolates exhibited 


\begin{tabular}{|c|c|c|c|c|c|c|c|c|}
\hline \multirow{2}{*}{$\begin{array}{l}\text { Study } \\
\text { location }\end{array}$} & \multirow[t]{2}{*}{ Longitude } & \multirow[t]{2}{*}{ Latitude } & \multirow[t]{2}{*}{ Soil pH } & \multirow[t]{2}{*}{ Soil type } & \multirow{2}{*}{$\begin{array}{c}\text { Rain fall } \\
(\mathrm{mm})\end{array}$} & \multirow{2}{*}{$\begin{array}{c}\text { Altitude } \\
\text { (Masl) }\end{array}$} & \multicolumn{2}{|c|}{$\operatorname{AAT}\left({ }^{\circ} \mathrm{C}\right)$} \\
\hline & & & & & & & Minimum & Maximum \\
\hline W/Genet & $7^{\circ} 192^{\prime} \mathrm{N}$ & $38^{\circ} 382^{\prime} \mathrm{E}$ & 6.4 & Sandy clay loam & 1000 & 1876 & $12.02{ }^{\circ} \mathrm{C}$ & $26.72{ }^{\circ} \mathrm{C}$ \\
\hline Hawassa & $7^{\circ} 05^{\prime} \mathrm{N}$ & $39^{\circ} 29^{\prime} \mathrm{E}$ & 7.2 & Sandy loam & 964 & 1652 & $12.94^{\circ} \mathrm{C}$ & $27.34^{\circ} \mathrm{C}$ \\
\hline Allagae & $7^{\circ} 43^{\prime} \mathrm{N}$ & $38^{\circ} 36^{\prime} \mathrm{E}$ & 8.57 & Clay loam & 510 & 1594 & $13.44{ }^{\circ} \mathrm{C}$ & $26.61{ }^{\circ} \mathrm{C}$ \\
\hline Qoqa & $8026^{\prime} \mathrm{N}$ & 3901 'E & - & Clay soil & 830.9 & 1604 & $13.68^{\circ} \mathrm{C}$ & $28.30^{\circ} \mathrm{C}$ \\
\hline Holleta & $9003^{\prime} \mathrm{N}$ & $38030^{\prime} \mathrm{E}$ & 5.5 & Nitosol & 1100 & 2390 & $6.13^{\circ} \mathrm{C}$ & $22.20^{\circ} \mathrm{C}$ \\
\hline Debrazeit & $38058 \mathrm{E}$ & $80044 \mathrm{~N}$ & 6.9 & Vertisol & 851 & 1891 & $11.42^{\circ} \mathrm{C}$ & $26.31^{\circ} \mathrm{C}$ \\
\hline
\end{tabular}

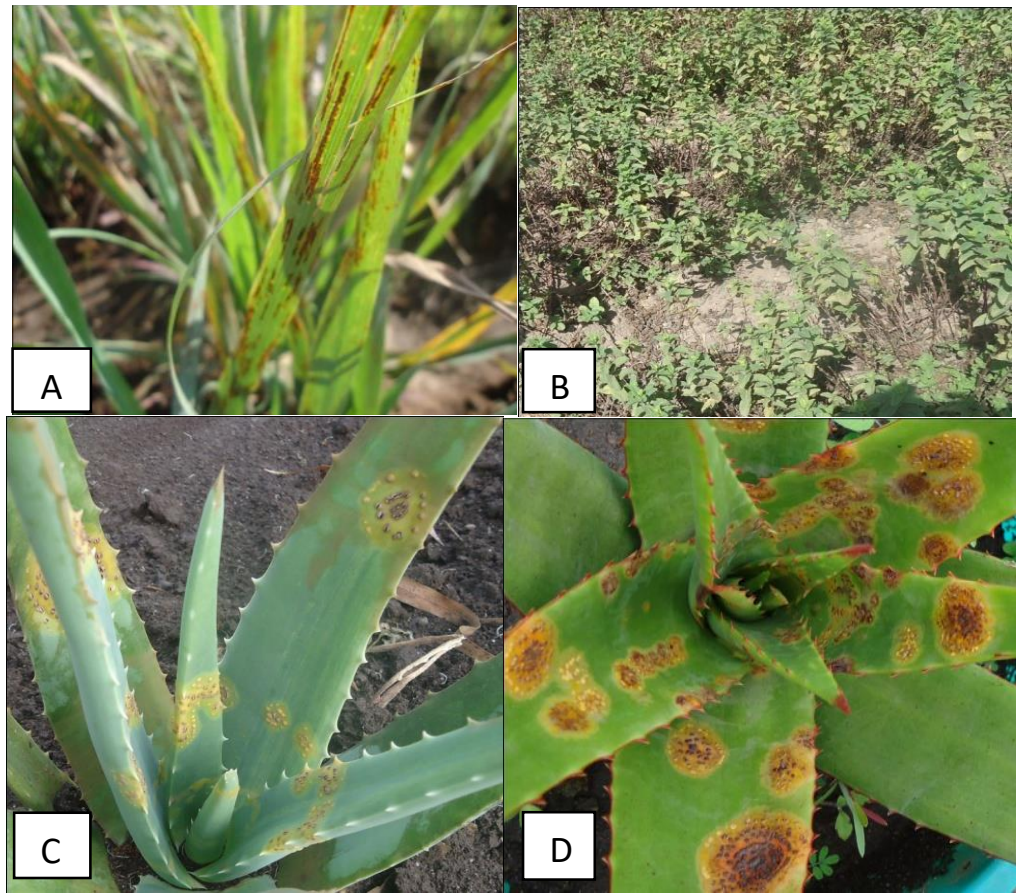

Fig 1. Rust diseases: A. Lemon grass rust (P. nakanishikii), B. Spear mint rust (P. menthae), C. Aloe vera rust (U. aloes) in field condition and D. Aloe vera rust in pots.

differences in conidial and spore morphologies. The morphological structures and characteristics of spores (various kinds) produced by them have been the basis of identification up to genus/species level. Based on morphological characteristics, the isolates were identified as P. nakanishikii, P. menthae, A. solani, U. aloes, Fusarium spp. and Phoma ssp. (Table 2).

\section{Lemmon grass (Cymbopogon citratus (DC) Stapf)}

Rust caused by P. nakanishikii was found to be a serious disease on lemon grass at WGARC, Alage, Hawassa and Qoqa. Heavily infected leaves become discolored and necrotic in streaked patterns that correspond to the leaf veins. The rust occurs in uredinial and telial forms, the former producing lighter brown pustules than the latter. Pustules are produced on both upper and lower leaf surfaces (Fig 1A). Most of the time associated with rust diseases requires serious during, high rainfall, humidity, and warm temperatures.

\section{Palmarosa (Cybopogon martini (Roxb.) Wats)}

On the other hand, phoma spp. was found major pathogens that caused root rot/wilt disease on Palmarosa grass at WGARC. Hot and moist weather condition favorable for phoma spp (Fig 3A\&3B).

\section{Spear mint (Mentha spicata L.)}

Puccinia menthae was identified as major fungal pathogen that causes leaf rust on spearmint at Wondo Genet and Debre Zeit. Previous study results showed that the disease caused up to $50 \%$ oil yield lose and also reduces the oil quality the plant. Although the disease affects some shoots in the early stages, it usually is noticed on older plants as orange to reddish-brown spots on the underside of the lower leaves. The rust disease appears as dark brown spots on the leaves as the fungus produces spores (Fig 1B).

\section{Rose Scented Geranium (Pelargonium graveolens L. Herit)}

Root rot and wilt caused by phoma spp. and Fusarium oxporum respectively, were the major identified diseases on Rose Scented Geranium at Wondo Genet and at Holleta. The wilting generally starts from older leaves and progresses to the younger foliage. Fusarium infected leaves become yellow and finally wilted. Initial symptoms often occur as the plant is beginning wilting may occur in one runner on a plant may wilt and collapse, with the rest of the runners remaining healthy (Fig 3C\&D). It is warm-weather disease. Pathogen is soil born and can remain in the soil for many years.

\section{Chamomile (Matricaria chamomile L.)}

Powdery mildew caused by (Erysiphe cichoracearum) was determined to be a minor disease and aphid was damage 
Table 2. Major identified diseases of Prioritized Aromatic and Medicinal plants.

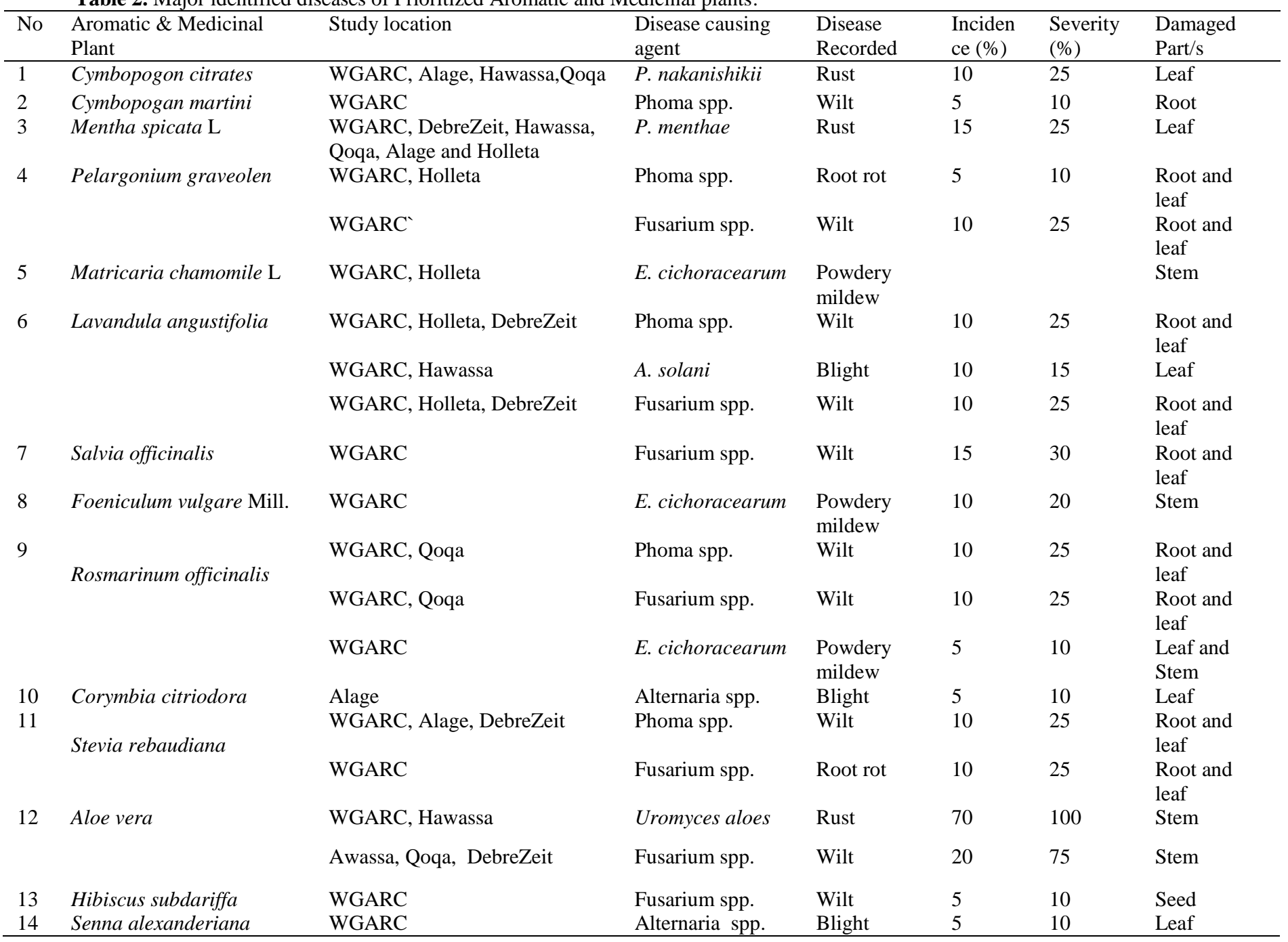

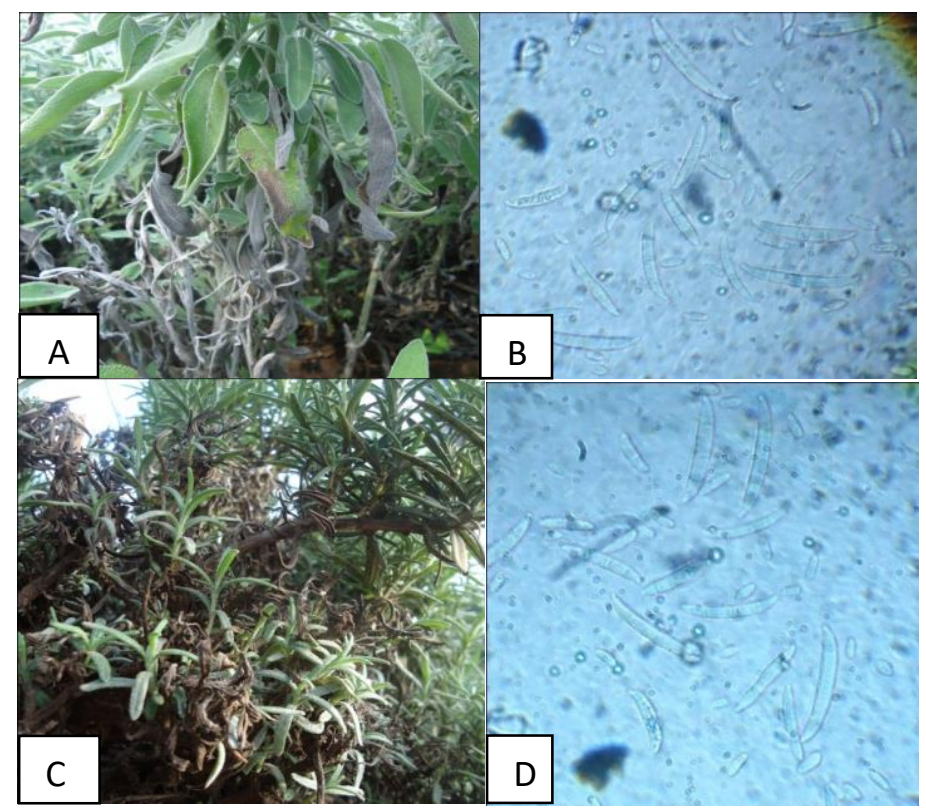

Fig 2. Diseases caused by Fusarium wilt: A. Sage fusarium wilt in field condition B. Sage spore of F. oxysporum, C. Rosemary fusarium wilt in filed condition, D. Rosemary spore of $F$. oxysporum. 
Table 3. Major identified insect pest of Prioritized Aromatic and Medicinal plants.

\begin{tabular}{|c|c|c|c|c|c|c|c|}
\hline $\begin{array}{l}\mathrm{N} \\
\mathrm{o}\end{array}$ & $\begin{array}{l}\text { Aromatic and Medicinal } \\
\text { Plant }\end{array}$ & Study location & $\begin{array}{l}\text { Insect Pests } \\
\text { Recorded }\end{array}$ & Order & Family & $\begin{array}{l}\text { Percent } \\
\text { Damage }(\%)\end{array}$ & Damaged Part/s \\
\hline 2 & Matricaria chamomile $\mathrm{L}$ & WGARC, Holeta & Aphid & Homoptera & Aphididae & 25 & Stem \\
\hline 4 & Rosmarinum officinalis & $\begin{array}{l}\text { WGARC, Hawassa, } \\
\text { Qoqa }\end{array}$ & $\begin{array}{l}\text { Cushiony } \\
\text { scale insect }\end{array}$ & Hemiptera & Argarodidae & 25 & Stem and Leaf \\
\hline 5 & Corymbiacitriodora & WGARC & Termite & Isoptera & Termitoidae & 30 & Stem and leaf \\
\hline 6 & Artemisia rehan & WGARC & Aphid & Homoptera & Aphididae & 45 & Stem \\
\hline 8 & Senna alexanderiana & WGARC & Termite & Isoptera & Termitoidae & 10 & Stem \\
\hline
\end{tabular}

All laboratory and field figures are taken during the study observations.

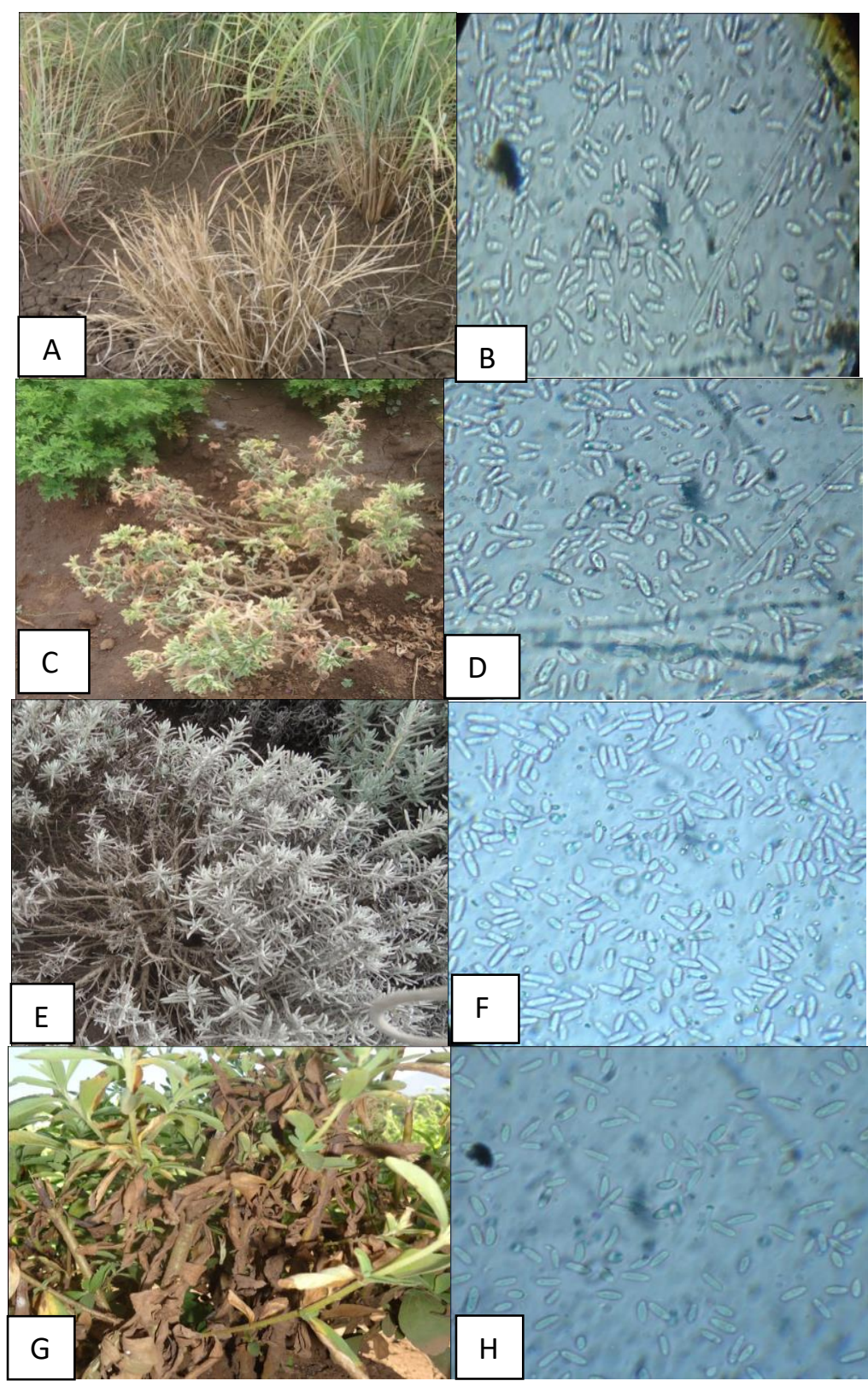

Fig 3. Disease caused by Phoma spp.: A. Palmarosa Phoma spp. in field condition, B. Palmarosa spore of Phoma spp. C. Rose Scented Geranium Phoma spp. in field condition, D. Rose Scented Geranium spore of Phoma spp. E. Lavander Phoma spp. in field condition, F. Lavander spore of Phoma spp. G. Stevia Phoma spp. in field condition H. Stevia spore of Phoma spp. 


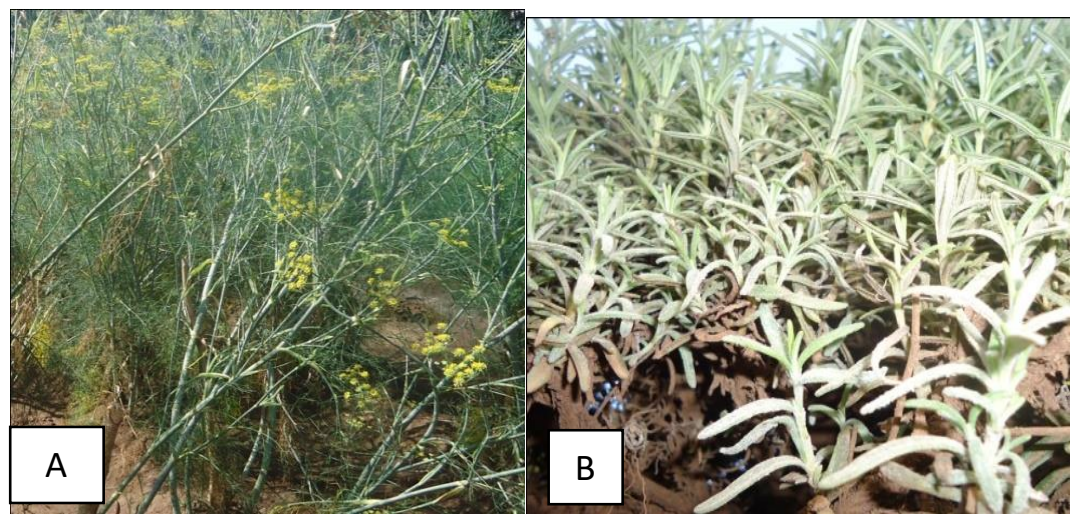

Fig 4. Disease caused by Powdery mildew: A. Funnel Powdery mildew in field condition, B. Rosemary Powdery mildew in field condition.

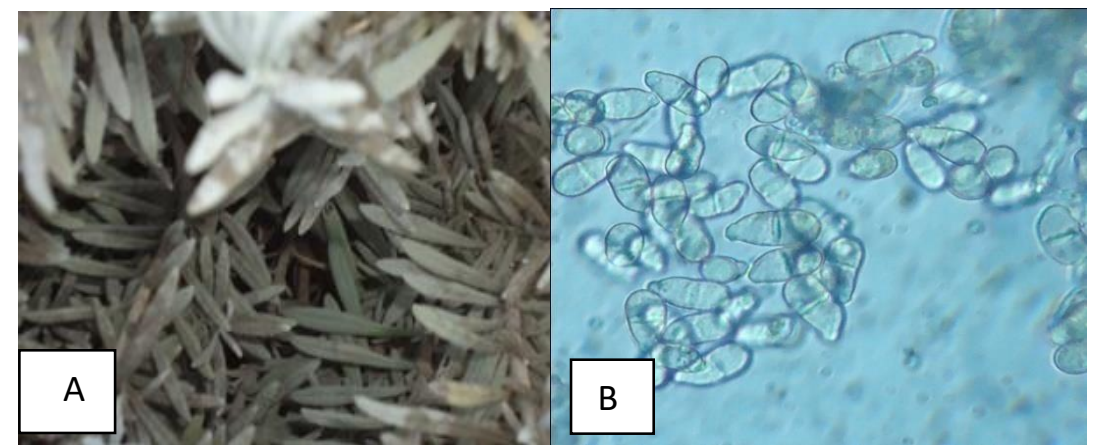

Fig 5. Disease caused by blight: A. Lavender A. solani in field condition, B. Lavender spore of A. solani.

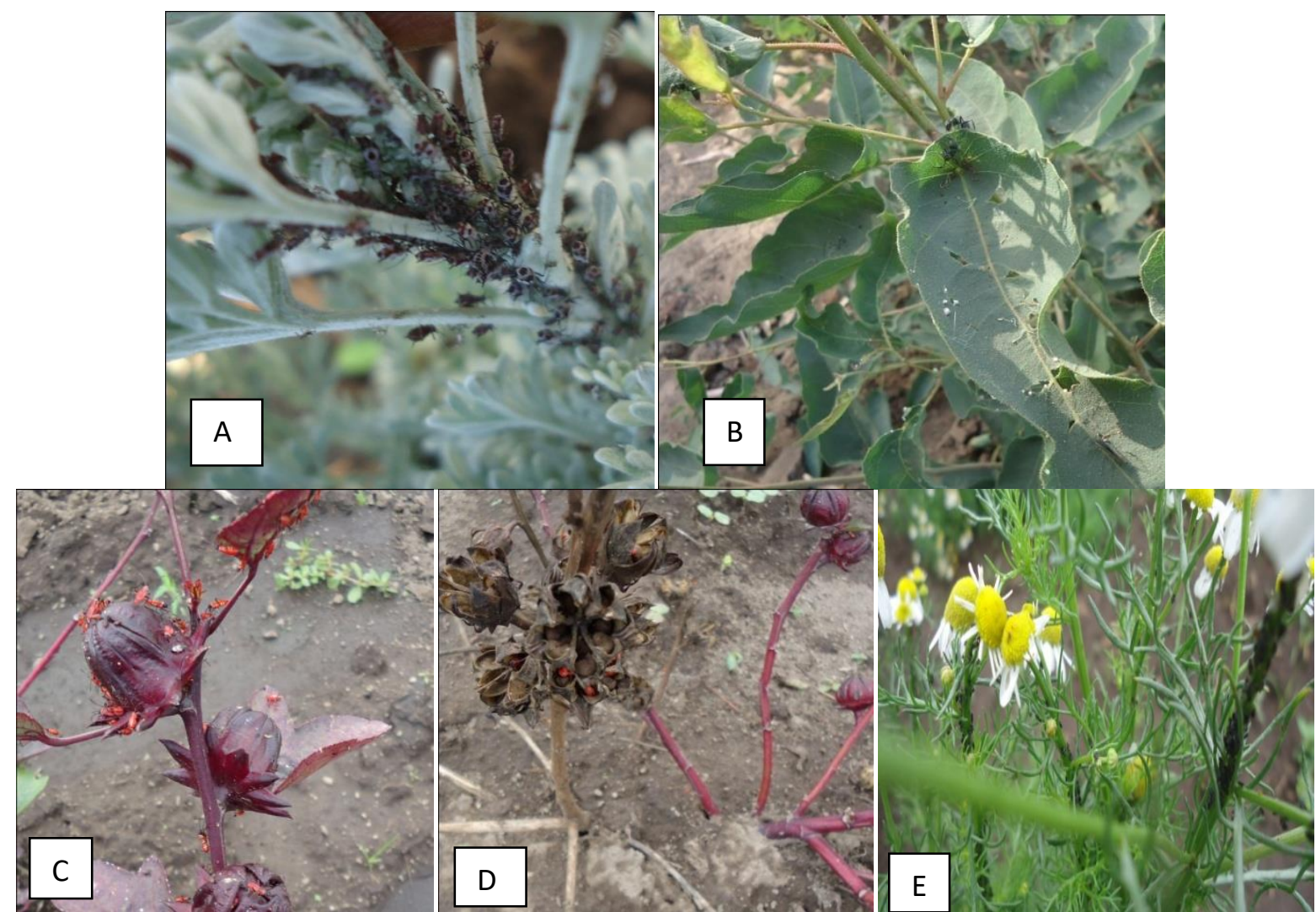

Fig 6. Insect pest damages: A. Ariti damaged by Aphid, B. Citron Scented Gum damaged by Termite, C. Hibiscus Plant bug early damaged, D. Hibiscus Plant bug Sevier damage E. Chamomile damaged by Black aphid. 
25\% which is significant effect on Chamomile at Wondo Genet and Holleta Agricultural Research Center (Fig 6E).

\section{Lavender (Lavandula angustifolia $\mathbf{L}$. )}

Lavender is highly infected by both Fusarium and Phoma spp. at Wondo Genet, Hawassa, Alage and Debrezith (Fig 3E $\&$ F). Both pathogens caused wilting disease to the plant. On the other hand, Alternaria solani caused blight disease with 10 and $15 \%$ incidence and severity respectively at Wondo Genet and Hawassa (Fig 5A \& B).

\section{Ariti (Artemisia rehan)}

No disease was recorded on Ariti at all study locations but, aphid is a major insect pest at Wondo Genet experimental site (Fig 6A).

\section{Funnel (Foeniculum vulgare Mill.)}

Powdery mildew caused by (Erysiphe cichoracearum) was found as a minor disease on Fennel (Fig 4A). The disease incidence reach $10 \%$ and aphid was damage $30 \%$ which is significant effect on Fennel at Wondo Genet Agricultural Research Center.

\section{Rosemary (Rosmarinus officinalis L.)}

Fusarium wilt and root rot, Powdery mildew caused by $F$. oxporum oxporum, Phoma spp. and E. cichoracearum respectively, was determined to be major diseases on Rosemary at Wondo Genet. (Fig 4B) Soil-borne pathogens have caused root rot and wilting disease that resulted yield losses on infected plants all over the world (Deeksha et al., 2009; Yangui et al., 2008). Our findings confirmed that these major soil-borne pathogens $F$. oxysporum and Phoma spp. were the main casual agents of Rosemary wilting disease of collected samples in the study areas (Fig 2C\&D).

\section{Citron Scented Gum (Eucalyptus citrodora Hook.)}

Termite is a major insect found in Citron Scented Gum at Wondo Genet and at Alage site leaf blight was observed. E. citriodora, when young, is liable to attack by termites, but it is attacked less by ants than most eucalyptus. Termites infestation often show no external signs of their presence nor are adverse effects always caused. The most common early symptoms of infestation are yellowing, wilting and drying of leaves, and the death of shoot tips or whole branches on an otherwise healthy-looking tree (Fig 6B).

\section{Sage (Salvia officinalis L.)}

Fusarium wilt ( $F$. oxporum) the most prevalent disease of Sage, bug and leaf hopper (Cicadella viridis) insect pest observed. Massive dying out of sage seedlings infected by $F$. oxysporum was observed in Wondo gent experimental field (Fig 2A\&B). The disease is most severe when air and soil temperatures are high and is more likely to occur in poorly drained soil. The fungus can persist in most soils indefinitely, because of its ability to colonize the roots of a number of weeds and its ability to produce resistant spore structures.

\section{Stevia (Stevia rebaudiana Bertoni L.)}

Root rot caused by Phoma spp. and Fusarium wilt disease was found in Stevia at all study location except at Holleta. Fusarium species were the most prevalent in the tested samples. Their spores survived the drying conditions and can remain dormant for several months (Fig 3G\&H).

\section{Hibiscus (Hibiscus sabdarifa L.)}

Plant bug and aphid were determined to be major insect pest on Hibiscus at Wondo Genet and Hawassa site. Plant bugs appear to insert their mouth stylets into host plant tissues and inject a tissue dissolving saliva. They then suck out the liquefied plant tissues. This produces a typical sunken lesion of circular (Fig 6C \& D). Feeding on immature pod can cause considerable damage. Occasionally, the lesion spots dry and fall out, producing small holes in leaves.

\section{Aloe (Aloe vera)}

Rust caused by $U$. aloes was the prevalent disease at Wondo Genet. The disease produces small, pale yellow spots on leaves which expand and turn brown. Orange spore masses on underside of leaves may drop from plant. Basal stem rot (Fusarium spp.) disease was observed at Hawassa, Holleta and Qoqa experimental site (Fig 1C\&D).

\section{Discussion}

Fungal pathogens show distinct variations in morphological characteristics that can be used for identification of the fungus under investigation up to genus level and sometimes up to species level with some certainty (Barnett and Hunter's, 1999). C. citratus rust disease was collected in medicinal gardens in the municipality of Seropédica, State of Rio de Janeiro. The fungus was identified as $p$. nakanishikii. (Uredinales). This disease first observed in Brazil (Koike, 1999). Citronell grass is grown commercially in the undulating lands of southern part of Sri Lanka and is found to be heavily diseased with foliar rust caused by puccinia nakanishikii. Rust one of the economically important diseases. Mainly the major important part of citronella grass leaves are the harvestable product for the extraction of essential oil (Bandara, 1981).

Rust on mint caused by puccinia menthe causes severe crop losses. It is one of fully cycle occurs on many species and genera of labiatae. The disease is more sever in some geographical areas than others, but the fungus is autoecious (Baxter, 1953 and Fletcher, 1963).

Geranium is attacked by root rot and wilt complex, caused by $F$. oxysporum and $R$. solani which shows the significant losses every season, in numerous states of India, The root-rot and wilt complex has emerged as one of the major problems for its cultivation in the region. Survey of rose-scented geranium growing area of Garhwal hills revealed that the root rot and wilt complex disease incidence ranged from 18 to 46 per cent. The most common symptoms of the disease are stem rot and root rot in growing and fully grown plants. The wilted leaves turn yellow, dry, turn black and are shed. In later stage, the entire plant is wilted within few days. Stems and roots turn black showing browning or blacking of the xylem vessels (Kalra 1988 and 1998).

Powdery mildew is considered one of the most important diseases attacking chamomile plant in its different cultivated areas. This disease was detected in Egypt for the first time in 1970. Then, the causal pathogen was identified as the fungus Sphaerotheca fuliginea Schlect. Fr. poll Chamomile powdery mildew frequently occurs in the open field, estimated percentages of infection reaching 20-80\%. Disease symptoms are shown up as powdery spots on leaves, stalks and small shoots on the lower parts of the plant, then the infection 
progressively increase to the upper parts of plant. These spots are characterized as white color in the beginning of infection, and then turn to gray color. In the severe infection, diseased plant seems as covered with layer form talk powder and this causes great damage for plant foliar. Since; this disease has negative effect on the quantity and quality of inflorescences yield regarded to the major purpose of chamomile plantation (Hilal et al., 1998).

Powdery mildew (Leveillula taurica var languinosa Salm.) Powdery mildew appears on the crop in February-March in Rajasthan. The disease results in heavy loss in yield. The green foliage, tender stem and branches get infected. Talcum like powder spreads on whole of the plant. The plant gets dried under severe infection (Chattopadhyaya and Maiti 1990).

Root rot and wilting of Rosemary trees causes yield losses under various conditions. The infections of Rosemary plants are facilitated by wet conditions, but the fungus can grow rapidly through the plant roots when the plants were moisture stressed. However, there is no general perfect method to be used in all instance of soil borne pathogens control (Hall, 1996).

Rosemary plants suffer from wilting disease which resulted yield reduction and economic problem recently. Although three mentioned fungal pathogens were identified as major agents of wilting on Rosemary, other soil borne pathogens such as bacteria and nematode species can also be associated in the wilting disease (Modupe et al., 2007).

The most important infectious diseases of sage in European countries are Antracnosis caused by Colletotrichum dematium, Ascochitosis caused by Ascochyta sclarea and root rot caused by Rhizoctonia solani. Economically important pathogens in Italy and Spain include Phomopsis sclarea, Phodosphaera inequalis, Erysiphae polygoni and Sclerotinia sclerotiorum. In 1995 massive dying out of sage seedlings infected by Fusarium oxysporum was observed in California, USA (Subbiah, 1996; Voltolina, 2001).

In a pathological survey in Jabalpur, Seoni, Balaghat, Chhindwara, yielded a rust pathogen responsible for severe infection. This results in a qualitative and quantitative loss of the gel of Aloe vera (Soni et al., 2011).

Comprising to $50 \%$ of all isolates recovered from diseased plants, Fusarium spp., Phoma ssp., P. nakanishikii, $P$. menthae and $U$. aloes were determined as the most important limiting factors for $S$. officinalis, $R$. officinalis, $S$. rebaudiana, $L$. angustifolia, $C$. citrates, $M$. spicata and $A$. vera production in Ethiopia. Especially, F. oxporum was found in most of the investigated fields and observed to cause the destruction of all products in some S. officinalis and $R$. officinalis fields during the surveys. Similarly the most important infectious diseases of sage in European countries are antracnosis caused by Colletotrichum dematium, ascochitosis caused by Ascochytasclarea and root rot caused by Rhizoctonia solani.

The isolates identified as Fusarium spp.and Phoma spp. were highly pathogenic and caused disease symptoms including root rot, wilt and death of the plant. Similarly In previous studies, F.oxysporum was reported and isolated on cumin seed (Cuminum cyminuml) by other researchers (Ershad, 1996). Similarly, some aromatic and medicinal plants are susceptible to a variety of insect pests including aphids, scale, mealy bugs, thrips and mites. Insect diversity on AMPs at all study locations is shown in Table 3. It comprised belonging to 4 families and pertaining to 3 orders namely: Isoptera, Homoptera and Hemiptera. The highest number of insect pest recorded in this study was aphid and the lowest number was recorded on termite species of insect pest.

The insect species were listed, systematically according to their taxonomy and also arranged according to their economic importance (injurious and beneficial insects) and show a list of the insect species recorded by different traps and by handing collection from different sites in six localities of aromatic and medicinal plants of different four seasons. Data revealed the presence of three insect species belonging to four families and three orders. The maximum number of species was that of Homoptera followed by Isoptera and Hemiptera.

The survey also revealed that the largest number of species was collected during April May, and June respectively. The lowest numbers were recorded on Senna alexanderiana (Isoptera) respectively. Species of Homoptera (Aphid) were the most representative species in all months during the period of the survey.

\section{Materials and methods}

\section{Study site}

The study was conducted at different locations namely; Holata, Debrezeith, Qoqa, Alage and Hawassa from 2011 to 2015.The study locations belong to three agro-ecological zones (high, middle and lower altitudes) of Ethiopia (Table 1).

\section{Plant materials}

Infected parts of Cymbopogon citrates, Cybopogon martini, Mentha spicata L., Pelargonium graveolens L. Herit, Matricaria chamomile L., Lavandula angustifolia L., Artemisia rehan, Foeniculum vulgare, Rosmarinus officinalis L., Eucalyptus citrodora, Salvia officinalis L., Alloysia triphylla L., Stevia rebaudiana Bertoni L., Hibiscus sabdarifa L. and Aloe vera were randomly collected from six study locations. Disease severity and incidence was measured using visual assessment key adapted by Beresford and Mulholland (1987). Disease incidence was calculated using the following formula.

Incidence $=$ Number of diseased plants X 100 Total number of plants examined

Similarly, disease severity was assessed using the following formula.

Severity $=\underline{\text { Area of plant tissue affected } \times 100}$

$$
\text { Total area }
$$

The collected samples were placed in polyethylene bags and then transported to the laboratory. Approximately, $2 \mathrm{~cm}$ long of infected parts of each plant species were cut into pieces between the healthy and the infected parts by using sterile scalpel. Then, the tissue segments were agitated in $10 \%$ chlorox sodium hypochlorite for 2 minutes. The tissues were rinsed three to four times in sterile distilled water and airdried. Five pieces of dried tissues were put onto PDA media in a Petri dish with five replications and then incubated at room temperature $\left(25 \pm 2^{0} \mathrm{C}\right)$ for 7 to 10 days. Different fungal colonies grown from different pieces of samples were systematically transferred separately on to a new PDA plates with three replications to obtain pure cultures.

\section{Identification of fungal pathogens using morphological characteristics}

The fungi were observed under the compound microscope to determine their morphological characteristics. To make the 
fungi more visible under the microscope, oil immersion was used as stain. The vegetative hyphae and the shape of conidia were observed to identify the morphological characteristics of the fungi. Pictures of all these characteristics were captured using digital camera at $40 \mathrm{X}$ magnification for further identification. Reference literatures were also used to aid the identification. The observation was focused on the characteristics of the fungi such as color and form of the spores, the partitioning and branching of mycelium. The identified fungi were described and then isolates were grouped into different fungal genera.

\section{Insect identification}

Optimal timing of sampling depends upon the life history and beneficial insect and also on the crop and environmental conditions. Both insects and plants develop quickly which is favorable under warm conditions. Visual assessment of insect pest aphid feed on phloem and can cause stippling or punctures that result in discoloration or mottling, honeydew, plant bug attack Grains attacked by piercing and sucking insects show a characteristic injury. Sampling done once per week and twice during infestation time is high and warm growing conditions.

\section{Conclusion}

This study is the first known extensive research for identification of the diseases and insect pest, associated with prioritized aromatic and medicinal plants in Ethiopia. Isolates of Fusarium spp., Phoma ssp., P. nakanishikii, P. menthae, $U$. aloes and A. Solani were identified in field aromatic and medicinal plants of Ethiopia. Fusarium spp., Phoma ssp., $P$. nakanishikii, $P$. menthae, $U$. aloes were found as the main limiting factor on $S$. officinalis, $R$. officinalis, $S$. rebaudiana, $C$. citrates, $M$. spicata, and $A$. vera production. Aphid were found common insect pest as the main limiting factor on $M$. chamomile, $F$. vulgare, and A. rehan production. The results obtained may assist in developing an integrated control program for these fungal diseases and insect pest. More detailed investigations should be carried out on genetic and pathogenic variability of these pathogens and biology of insect pest.

\section{Acknowledgment}

Author thanks Wondo Genet Agricultural Research Center and Aromatic and Medicinal plants Research project for providing all the necessary facilities and support. I extend my sincere thanks to Dr. Bekele Kassa for his kind support. My sincere thanks to Ambo plant protection research center (PPRC), and particularly mycology department of laboratory assistants for their help and offering me the laboratory facilities to carry out the research work.

\section{References}

Abebe D (1986) Traditional medicine in Ethiopia. The attempt being made to promote it for effective and better utilization. SINET: Ethiopian J Sci. 9: 61-69.

Bandara JMRS (1981) Puccinia rust of citronella and lemongrass in Sri Lanka. Plant Dis. 65:164-165.

Barnett HL, Hunter BB(1999) Illustrated Genera of Imperfect Fungi(fourth ed.), 218 pp.APS Press, St. Paul, Minnesota, USA.Subbiah VP, Riddick M, Peele D (1996) First report of Fusarium oxysporum on clary sage in north America. Plant Dis. 80:1080.
Voltolina G (2001) Salvia sclarea L. Plante Officinali. 2:112.

Beresford RM, Mulholland RI (1987) Mint rust on cultivated peppermint in Canterbury: disease cycle and control by flaming. NZ J Exp Agricu. 15: 229-233.

Chattopadhyaya SB, Maiti S (1990) Diseases of Betelvine and spices. ICAR, New Delhi.p.160.

Deeksha J, Hooda KS, Bhatt JC, Mina BL, Gupta HS (2009) Suppressive effects of composts on soil-borne and foliar diseases of French bean in the field in the western Indian Himalayas. Crop Prot. 28:608-615.

Ershad D (1996) Fungi of Iran. Ministry of Jihad-eAgriculture, Agricultural Research, Education and Extension Organization Iranian Research Institute of Plant Protection.

Gupta SK, Mukherjee A, Roy I, Saha G (2005) Insects and mites injurious to medicinal plants in India and their suggested management. In: Gupta SK \&Mitra BR (eds) Medicinal plants research and utilization:an overview. R.K.M.A, Narendrapur, pp. 245-251.

Hall R (1996) Principles and practice of managing soil borne plant pathogens, APS Press, St. Paul, Minnesota, USA. p. 330

Hilal AA, Harridy IM, AM Abo EL- Ela , Baiuomy MAM, EL-Morsy SA (1998) Studies on the commonly and newly occurring disease of seven medicinal and aromatic plants and yield losses in relation to some agricultural practices in Egypt. Egyptian J Appl Sci. 13 (7): 41- 60.

Japan Association for International Collaboration of Agriculture and Forestry (JAICAF, 2008) "Medicinal crops" in Ethiopia- Current status and future potentials (unpublished document).

Kalra A, Parameswaran TN (1988) Indian J Plant Pathol. 6: 82-83.

Kalra A, Parmeswaran TN, Ravindra NS (1998). J Mycol Pl Pathol. 28: 338-339.

Koike ST (1999) Rust disease on lemongrass in California. Plant Disease 83: 304-354.

Mihiret M, Begashaw M,Beemnet M (2015) Screening of Botanical extracts for the control of Japanese mint (MenthaarvensisL.) Leaf rust (Pucciniamenthae) in Greenhouse and field condition. Afr J Crop Sci. 3 (7): $201-$ 205.

Mihiret M, Begashaw M, Beemnet M (2015) Screening of botanical extracts for the control of Artemisia rehan (Artemisia absinthiumL.) Aphid (Coloradoaabsinthii Li.) in green house and field condition. Afr J Crop Sci. 3 (7): 196200

Modupe FA, Lembke A, Costa R, Speksnijder A, Smalla K (2007) Screening of bacterial isolates from various European soils for in vitro antagonistic activity towards Rhizoctonia solani and Fusarium oxysporum: Sitedependent composition and diversity revealed. Soil Biol Biochem. 39(11): 2818-2828.

Rashi M, Singh SP (2007) Shifting from Agriculture to Agribusiness: The Case of Aromatic Plants. Agricultural Economics Research Review. 20:541-550.

Singh R, Gangwar SP, Singh D, Singh R, Pandey R, Kalra A (2011) Medicinal plant Coleus forskohliiBriq.: Disease and management. Medic Plants. 3(1): 1-7.

Soni KK, Pyasi A, Tiwari Pooja, Verma RK (2011) Occurrence of Aloe vera rust (Uromyces aloës): A new record from Madhya Pradesh, India. J Mycol Plant Pathol. 41(4):644-646.

World Health Organization (WHO) (2002) WHO guidelines for good agricultural and collection practices (GACP) for 
medicinalplant.whqlibdoc.who.int/publications/2002 19241546271.pdf

Yangui T, Rhouma A, Triki MA, Gargouri K, Bouzid J (2008) Control of damping-off caused by Rhizoctoniasolani and Fusarium solaniusing olive mill wastewater and some of its indigenous bacterial strains. Crop Prot. 27(2):189-197.
Yirga G (2010b) Ethno botanical Study of Medicinal Plants in and Around Alamata, Southern Tigray. Northern Ethiopia Current Research Journal of Biological Sciences. $2: 338-344$. 